\title{
CALÁVIA SAEZ, Oscar. 2006. 0 Nome e o Tempo Yaminawa: etnologia e história dos Yaminawa do rio Acre. São Paulo: Editora UNESP / ISA; Rio de Janeiro: NUTI. 479 pp.
}

Paulo Roberto Homem Oscar Calávia começou em 1991 sua pesquisa entre os Yaminawa da Terra de Góes Indígena Cabeceiras do rio Acre. Este livro é um fruto maduro de um trabalho que (UFPR) resultou na tese de doutorado do autor em 1995, mas que apenas em 2006 veio a ser publicada. Digo maduro porque esse tempo permitiu ao autor absorver e transformar a escassez documental e etnográfica em uma análise densa e complexa que se debruça sobre o sentido da história Yaminawa enquanto constituída pelo sentido Yaminawa da história, e vice-versa. Não há aqui aquelas dicotomias que quase invariavelmente emergem com a evocação a um só tempo de Antropologia e História. Com um sorriso poderíamos dizer que não obstante pesquisar em região de cabeceiras, há muito o autor passou pelo encontro das águas.

Mas antes de alcançar este altiplano, no qual a história Yaminawa ganha sentido através do ponto de vista e das formas de ação dos próprios indígenas, Calávia percorre através de sua etnografia um caminho tortuoso que adentra a organização social, o espaço, o cotidiano e a economia deste povo Pano, em busca de encontrar as fronteiras do sujeito da história que será tematizado em seguida. Neste trajeto nos ensina que depositar demasiadas fichas na tentativa de conceber um sistema de parentesco para os Yaminawa que se adeque rigidamente aos modelos formais é contraproducente. O parentesco Yaminawa opera com uma terminologia do tipo dravidiano que se mescla a um modelo australiano, algo que o autor explana com muita propriedade; no entanto, entre o formalismo do modelo e o cotidiano encontra-se um abismo de inconsistências e contradições. Um iniciante poderia se desesperar diante de tal quadro, porém deste jogo de incertezas e ruídos Calávia soube retirar a positividade e o sentido dos dados.

A crônica Yaminawa elaborada a partir de registros históricos, relatos orais e da comparação com outros grupos da região nos fornece um panorama de diversos momentos mais ou menos detalhados da trajetória deste grupo que retrocede dos tempos atuais até a época anterior ao boom da borracha. Mas ao buscar traçá-la o autor se vê perante o inevitável desafio de "descobrir" afinal quem foram ou são estas pessoas que são reconhecidas (e muitas vezes apenas contextualmente se 
reconhecem) enquanto Yaminawa, "gente do machado", uma vez que o próprio nome deste grupo foi atribuído também a tantos outros grupos espalhados em ao menos seis bacias hidrográficas distintas.

Isto feito, Calávia parte para a relação muito fértil entre história-sociologia- mitologia, primeiramente analisando o papel do Inca no plano cosmológico Pano e sua significativa ausência entre os Yaminawa, e depois discorrendo sobre conceitos que permeiam este universo de significação. Dentre estes sua análise sobre o conceito yuxin é sobremaneira interessante, pois é ele o mediador entre os diferentes planos do mundo, é poder transformador por excelência (o que neste contexto é de grande significado): yuxin é ao mesmo tempo a linguagem dos pajés, fonte de significados, é sobre os yuxin das pessoas que seu poder é exercido, seja para cura ou malefício, o yuxin de certos animais é também professor, afim dos especialistas xamânicos etc. A yuxindade, como já foi chamada esta concepção que reconhece poder de agência em praticamente tudo que há no mundo, é um viés através do qual Calávia nos permite acessar sua reflexão mais propriamente histórica.

A riqueza da interpretação verdadeiramente etno-histórica proposta pelo autor nasce de uma tessitura realizada a partir de sua percepção apurada e de seu grande fôlego teórico que, ao serem entrelaçados com os shedipawo narrados pelos Yaminawa, encontrou um espaço privilegiado de reflexão. Os shedipawo, literalmente "história dos antigos", são, sobretudo, narrativas sobre um tempo e um espaço outros, na maioria das vezes dificilmente identificáveis cronológica ou geograficamente. Essa paisagem que Calávia chama mítica não é desenvolvida necessariamente em referência ao passado, o mito aqui ocupa uma posição sincrônica àquele que o narra, classificando e dando sentido às diferenças, por exemplo, entre os animais da floresta, entre os gêneros feminino e masculino, mas também explicando a maneira através da qual os indígenas adquiriram certos conhecimentos. No shedipawo a constante é a transformação e a comunicação entre os diferentes seres: um índio pode se tornar esposo de uma sucuri e ir viver embaixo d'água na aldeia das cobras, para em seguida retornar à terra e a sua família "humana"; uma paca pode virar índia para se vingar do caçador que matou seu marido; um macaco capelão pode trocar de cabeça com o macaco zog-zog "só para experimentar" e esse perder definitivamente a capacidade de cantar alto etc. Os exemplos são tão vastos quanto é a criatividade indígena.

Esta forma narrativa pode ser encontrada senão na totalidade, na maioria dos povos Pano, constituindo em certo plano uma homogeneidade talvez só encontrada na própria língua por eles falada. Tal homogeneidade, no que se refere ao conteúdo, é facilmente observada entre Katukina, Jaminawa, Kaxinawa, Yawanawa etc. Em todos estes povos e em outros mais podemos encontrar narrativas que versam sobre os mesmos temas; no entanto, isto não significa que a forma como este conteúdo é expresso seja similar, e o autor bem demonstra isto.

A falta de exegese e a tendência a dividir em vários relatos aparentemente sem relação alguma aquilo que em outros povos Pano constitui um mesmo mito, é uma característica marcante dos Yaminawa. E neste fato, que a um observador inexperiente poderia passar desapercebido, Calávia encontra ressonâncias dos princípios sociológicos deste grupo. Desordem narrativa, desordem social (p. 295), é o nome que dá a um dos tópicos do livro e não o faz por acaso. Esta aparente desagregação Yaminawa, que diferentes atores indígenas e indigenistas tendem a entender, desde os primeiros relatos documentais de que se tem notícia até os dias de hoje, como evidências de aculturação, de desregramento, da influência do contato etc., é para Oscar constituinte da própria tradição deste povo. Na "etnografia das ausências", que é como chama sua 
própria pesquisa entre os Yaminawa (ausência de nomes, penas, rituais, genealogias etc.), Calávia encontra não esses atributos negativos que recorrentemente se atribui aos Yaminawa, e sim mecanismos de produção e reprodução de uma forma muito singular de estar no mundo. A recusa de composições harmônicas, a ausência de um sujeito histórico coletivo que poderia perpassar o tempo e as gerações criando um sentido de unidade ao grupo, o constante jogo que oscila entre fissão e fusão, isto tudo é coerente com a maneira pela qual os Yaminawa se apropriam do acervo mitológico Pano e com a maneira através da qual a partir dele constituem sua história e sua (des)organização social e política.

O shedipawo, não obstante "ser história e perfazer história", permanece, em sua virtualidade latente, num espaço do pensamento indígena bastante distante daquele que um historiador acadêmico conceberia como fato histórico. Em certo momento do livro Calávia aproxima os shedipawo da noção de ficção (p. 377), atribuindo ao bom narrador do shedipawo uma posição análoga à do bom piadista, no sentido de que para ambos o dilema verdade-mentira não se coloca. Em vários sentidos a sensação é de que é justamente assim que estas narrativas se passam; no entanto, a análise de certas formas narrativas, quando expressas em primeira pessoa, pode complexificar a questão ao trazer os conteúdos míticos para um tempo mais definido, mais próximo, o tempo de vida.

O relato de Clementino (pp. 195-6), considerado o melhor narrador de histórias entre os Yaminawa, é bastante ilustrativo neste sentido. Ao fundir na mesma narrativa temas que tenderíamos a compreender como de gêneros muito distintos ("história do contato" com os brancos e "mito" do macaco), Clementino faz mais do que explicar um tempo de precariedade e ignorância que somente a relação com um outro permitiu aos índios superar (com os brancos acessaram o metal, com os macacos aprenderam o ato sexual). A forma como Clementino associa um shedipawo bastante conhecido a um "relato do contato" igualmente recorrente coloca ambos, brancos e macacos, em uma posição bastante similar: possuem conhecimentos que aos índios faltavam, não mais que isso.

Não há dúvidas que a cosmologia ressoa na organização social e na história destes grupos, como bem nos demonstra Calávia, até mesmo quando pela negativa, como é o caso Yaminawa. Narrativas em primeira pessoa como a acima referida mesclam os conteúdos cosmológicos com a experiência vivida dos sujeitos históricos. $\mathrm{O}$ aprendizado do ato sexual com o macaco foi análogo ao acesso ao terçado, mas isso sendo contado enquanto um tempo outro, distante. No entanto, é comum a referência de serem os pajés, através das canções e da ingestão de sua bebida ritual, aqueles que transitam neste espaço-tempo dos shedipawo, e nele os animais são vistos enquanto espíritos e também enquanto humanos, por isso se comunicam e estabelecem alianças com estes mediadores de mundos, ensinando-lhes cantos, plantas medicinais etc. Através destes especialistas xamânicos é que o acervo mitológico é muitas vezes atualizado e que os princípios sociológicos e o sentido histórico continuam sendo constituídos.

Paulo Roberto Homem de Góes é bacharel em Ciências Sociais e mestrando do Programa de Pós-Graduação em Antropologia Social da Universidade Federal do Paraná. 
208 